Herzschr Elektrophys 2021 · 32:365-370 https://doi.org/10.1007/s00399-021-00786-z Received: 9 April 2021

Accepted: 16 June 2021

Published online: 16 July 2021

(c) Springer Medizin Verlag $\mathrm{GmbH}$, ein Teil von Springer Nature 2021

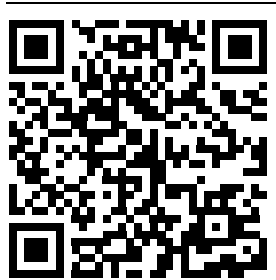

Scan QR code \& read article online

\section{The role of anticoagulation in preventing myocardial infarction and improving outcomes in COVID-19 patients}

\author{
Tigran Chilingaryan ${ }^{1,2,6} \cdot$ Sona Tribunyan ${ }^{5} \cdot$ Hripsime Poghosyan $^{3} \cdot$ Knarik Sargsyan $^{2}$. \\ Hasmik Hovhannisyan ${ }^{2,3} \cdot$ Kristine Karapetyan $^{4} \cdot$ Lyudmila Niazyan $^{2}$. \\ Hamlet Hayrapetyan ${ }^{1,3}$ \\ ' Department of Cardiology, Yerevan State Medical University after M. Heratsi, Yerevan, Armenia \\ ${ }^{2}$ National Centre of Infectious Diseases, Yerevan, Armenia \\ ${ }^{3}$ Cardiology Centre, Erebouni MC, Yerevan, Armenia \\ ${ }^{4}$ Nork-Marash Medical Centre, Yerevan, Armenia \\ ${ }^{5}$ Evangelical clinic bethel, Bielefeld, Germany \\ ${ }^{6}$ Abovyan, Armenia
}

\title{
Abstract
}

Background: Coronavirus disease 2019 (COVID-19) is associated with cardiovascular (CV) complications including myocardial injury, myocarditis, arrhythmias, and venous thromboembolism. The infection is more severe in patients with pre-existing cardiovascular disease (CVD), where systemic inflammation due to cytokine storm, hypercoagulation, as well as high hematocrit and platelet (PLT) count may contribute to an increased CV risk. The authors hypothesize that anticoagulants and antiplatelets prevent miocardial infarction (MI) in patients with pre-existing CVD.

Methods: A cohort study enrolled patients with a confirmed diagnosis of COVID19. Clinical and laboratory data, total and CV mortality, as well as MI incidence and treatment regimens were compared according to the time of hospitalization: 40-day period in April-May (Group 1) and in October-November (Group 2).

Results: A total of 195 patients were enrolled: 93 in Group 1, with 36.5\%, and 102 in Group 2 with $38.2 \%$ pre-existing CVD. Group 1 was managed with infusion therapy; only $10.7 \%$ received anticoagulation. Group 2 received preventive anticoagulants, antiplatelets, and infusion therapy. In Group 1, seven cases of MI were recorded compared to only three in Group 2. No significant difference in overall mortality ( $4.3 \%$ vs $6.86 \%, p=0.441)$ and $\mathrm{MI}$ incidence $(7.5 \%$ vs $2.9 \%, p=0.149)$ was found, but significant differences were seen in the incidence of severe and critically ill cases between the groups ( $69.9 \%$ and $7.5 \%$ vs $75.5 \%$ and $20.6 \%, p<0.001)$.

Conclusions: Poorer outcomes in the early COVID-19 wave were associated with inadequate anticoagulation due to lack of knowledge about the new virus. Despite significantly more severe cases, there was no significant difference in overall mortality and $\mathrm{Ml}$ incidence in patients with anticoagulation.

\section{Keywords}

Pneumonia · Percutaneous coronary intervention · STEMI - Acute coronary syndrome · Thrombosis

\section{Introduction}

People of all ages can be infected by COVID19. People aged 60 years and older, as well as those with underlying medical problems such as high blood pressure, heart and lung diseases, diabetes, obesity, and cancer, are at higher risk of developing serious illness [10]. Involvement of the cardiovascular system is common in COVID-19 [1-6]. Myocardial injury is a common condition among patients hospitalized with COVID- 
Table 1 Clinical characteristics for the Group 1

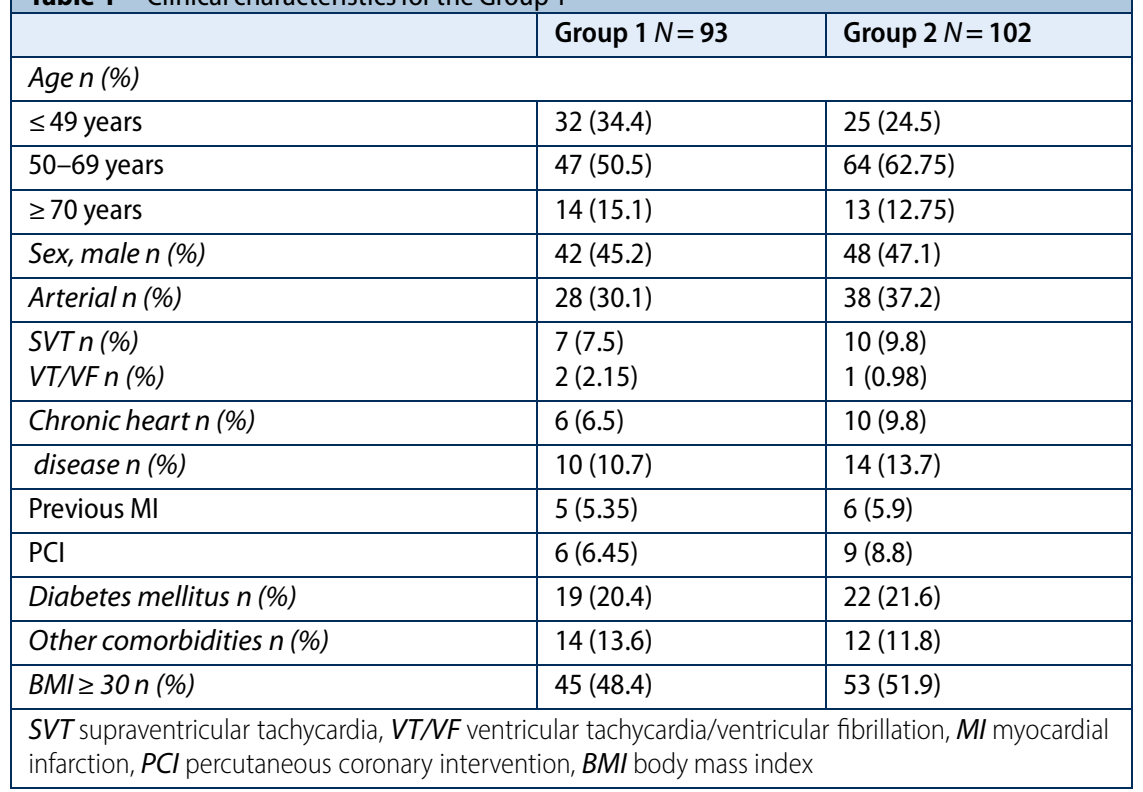

\begin{tabular}{|l|l|l|}
\hline \multicolumn{4}{|l|}{ Table 2 Treatment comparison between Group 1 and Group 2 } \\
\hline Treatment & Group 1 & Group 2 \\
\hline Aspirin 75-100 mg/day, $n$ (\%) & $23(24.7)$ & $31(30.4)$ \\
\hline Anticoagulation, $n(\%)$ & $10(10.75)$ & $102(100)$ \\
\hline Nadroparin, $n(\%)$ & $8(8, .6)$ & $22(21.56)$ \\
\hline $4000 \mathrm{U} /$ day & 0 & $44(43.13)$ \\
\hline $8000 \mathrm{U} /$ day & 0 & $8(7.8)$ \\
\hline $16,000 \mathrm{U} /$ day & 0 & $23(22.5)$ \\
\hline Heparin U/8 $h, n(\%)$ & $2(2.15)$ & $5(4.9)$ \\
\hline Xarelto $10-20 \mathrm{mg} /$ day $n(\%)$ & & \\
\hline
\end{tabular}

\begin{tabular}{|l|l|l|}
\hline \multicolumn{4}{|l|}{ Table 3 Laboratory test results for the two groups } \\
\hline Laboratory data & Group 1 & Group 2 \\
\hline PLT $(\mathrm{N}-150-400 \times 109 / \mu \mathrm{L})$ mean; range & $839 ; 366-1312$ & $722 ; 125-1010$ \\
\hline $\mathrm{HCT}(36-47 \%)$ mean; range & $38.4 ; 372-51.1$ & $38.2 ; 37-49.2$ \\
\hline D-dimer $(<0.55 \mathrm{FEU} / \mathrm{ml})$ mean; range & - & $2.3 ; 0.5-13.8$ \\
\hline INR $(0.85-1.2)$ mean; range & $0.98 ; 0.64-2.1$ & $1.02 ; 0.72-3.1$ \\
\hline APTT (25-43 sec) mean; range & $34.6 ; 27-43.8$ & $36.2 ; 25-44.5$ \\
\hline Fibrinogen $(200-400 \mathrm{mg} / \mathrm{dl})$ mean; range & $449.7 ; 225-635$ & $497.8 ; 240-675$ \\
\hline $\begin{array}{l}\text { PLT platelet, } H C T \text { hematocrit, INR international normalized ratio, APTT activated partial thromboplas- } \\
\text { tin time }\end{array}$ \\
\hline
\end{tabular}

19 and is associated with a higher risk of in-hospital mortality [1, 2]. COVID-19 has been associated with various cardiovascular complications including acute myocardial injury, myocarditis, arrhythmias, and venous thromboembolism [9]. Infection is severe in patients with pre-existing cardiovascular disease, and in these cases the systemic inflammatory response due to cytokine storm can lead to acute MI [7]. Ml caused by the rupture of atherosclerotic plaque resulting in intraluminal thrombus is defined as type $1 \mathrm{MI}$ [8]. Several potential mechanisms can contribute to the high risk of plaque destabilization and consequently to acute coronary ischemic syndromes in patients with systemic viral infection [11]. Viral products known as pathogen-associated molecular patterns entering the systemic circulation activate immune receptors on cells in existing atherosclerotic plaques and predispose to plaque rupture [12]. It is also believed that such pathogen-associated molecular structures activate inflammasomes and lead to the conversion of emerging procytokines into biologically active cytokines [13]. Infection and inflammation can also lead to coronary vascular endothelial dysfunction and cause vasoconstriction and thrombosis [14]. In these cases, patients usually present with dyspnea that is attributed to pneumonia-therefore MI can be easily overlooked.

With COVID-19 infection, the majority of Mls are type 2 and are related to the primary infection, as well as hemodynamic and respiratory impairment. However, hypercoagulation in COVID-19 can also predispose patients to fatal vascular events [15].

Furthermore, these patients also have high hematocrit and PLT values, which, in turn, contribute to the high risk of vascular events.

The authors hypothesize that the use of antiocoagulants and antiplatelets is vital for the prevention of acute coronary syndromes, especially in patients with preexisting cardiovascular diseases.

\section{Methods}

A prospective cohort study was conducted in patients with a confirmed diagnosis of COVID-19 admitted to Nork National Center of Infectious Diseases, Armenia. In all, 193 patients were divided into two groups according to the time of hospitalization: 40-day period in April-May (Group 1) and in October-November (Group 2). Severity of COVID-19 was defined according to the WHO scale criteria. Clinical and laboratory data, total and CV mortality, the incidence of $\mathrm{Ml}$, as well as treatment regimens were compared in the two groups.

\section{Results}

In Group 1, 21 (22.6\%) moderately, 65 (69.9\%) severely, and seven (7.5\%) critically ill patients were enrolled with a mean age of 49 (28-79), of which $45.2 \%$ were male. A total of 90 patients had pneumonia; in 11 cases lesions involved more than $50 \%$ of the lung parenchyma, and SpO2 fluctuated between 64-97\%. Acute respiratory distress syndrome (ARDS) was 


\begin{tabular}{|l|l|l|l|}
\hline Table 4 Endpoints \\
\hline Hospitalization, mean \pm SD (days) & $14.3 \pm 5.2$ & $14.1 \pm 4,6$ & \\
\hline MI $n(\%)$ & $7(7.5)$ & $3(2.9)$ & $p=0.149$ \\
\hline Mortality $n(\%)$ & $4(4.3)$ & $7(6.86)$ & $p=0.441$ \\
\cline { 1 - 2 } CV mortality $n(\%)$ & $3(3.2)$ & $1(0.98)$ & \\
\cline { 1 - 2 } SD standard deviation, $M I$ myocardial infarction, $C V$ cardiovascular \\
\hline
\end{tabular}

\begin{tabular}{|c|c|c|}
\hline & Results & Normal range \\
\hline WBC & 6.17 & $4-10 \times 109 / \mu \mathrm{L}$ \\
\hline LYM & 0.86 & $1-3.0 \times 109 / \mu \mathrm{L}$ \\
\hline NEU & 4.91 & $1.6-7 \times 109 / \mu \mathrm{L}$ \\
\hline PLT & 952 & $150-400 \times 109 / \mu \mathrm{L}$ \\
\hline $\mathrm{RBC}$ & 6.26 & $3.9-5.6 \times 1012 / \mu \mathrm{L}$ \\
\hline HGB & 154 & $110-160 \mathrm{~g} / \mathrm{l}$ \\
\hline CRP & 68 & $>5 \mathrm{mg} / \mathrm{l}$ \\
\hline D-dimer & 0.613 & $<0.55 \mathrm{FEU} / \mathrm{ml}$ \\
\hline PCT & 0.01 & $<0.05 \mathrm{ng} / \mathrm{ml}$ \\
\hline Ferritin & 790 & $13-350 \mathrm{ng} / \mathrm{ml}$ \\
\hline INR & 1.12 & $0.85-1.2$ \\
\hline APTT & 40.6 & $25-43 \mathrm{sec}$ \\
\hline Fibrinogen & 548 & $200-400 \mathrm{mg} / \mathrm{dl}$ \\
\hline Glucose & 25 & $<6 \mathrm{mmol} / \mathrm{l}$ \\
\hline \multicolumn{3}{|c|}{$\begin{array}{l}\text { WBC white blood cell count, } L Y M \text { lymphocyte count, NEU neutrophil count, } P L T \text { platelet count, } \\
R B C \text { red blood cell count, } H G B \text { hemoglobin } C R P C \text {-reactive protein, } P C T \text { procalcitonin, INR interna- } \\
\text { tional normalized ratio, APPT activated partial thromboplastin time, FEU fibrinogen-equivalent unit }\end{array}$} \\
\hline
\end{tabular}

\begin{tabular}{|l|l|l|}
\hline \multicolumn{3}{|l|}{ Table 6 Intensive care unit blood test results } \\
\hline & Results & Normal range \\
\hline WBC & 10.76 & $4-10 \times 109 / \mu \mathrm{L}$ \\
\hline LYM & 0.45 & $1-3.0 \times 109 / \mu \mathrm{L}$ \\
\hline NEU & 10.01 & $1.6-7 \times 109 / \mu \mathrm{L}$ \\
\hline PLT & 1345 & $150-400 \times 109 / \mu \mathrm{L}$ \\
\hline CRP & 19 & $>5 \mathrm{mg} / \mathrm{l}$ \\
\hline D-dimer & 1.23 & $<0.55 \mathrm{FEU} / \mathrm{ml}$ \\
\hline Ferritin & 821 & $13-350 \mathrm{ng} / \mathrm{ml}$ \\
\hline INR & 1.17 & $0.85-1.2$ \\
\hline APTT & 41.8 & $25-43 \mathrm{sec}$ \\
\hline Fibrinogen & 556 & $200-400 \mathrm{mg} / \mathrm{dl}$ \\
\hline $\begin{array}{l}\text { WBC white blood cell count, LYM lymphocyte count, } N E U \text { neutrophil count, PLT platelet count, } \\
\text { CRPC-reactive protein, INR international normalized ratio, } A P P T \text { activated partial thromboplastin } \\
\text { time, FEU fibrinogen-equivalent units }\end{array}$ \\
\hline
\end{tabular}

reported in eight cases. The mortality rate in Group 1 was 4.3\%. In all, 36.5\% of patients had pre-existing cardiovascular diseases (arterial hypertension: 28, arrhythmia: nine, chronic heart failure: six, coronary artery disease: 10 , previous MI: five). A total of 19 patients were regularly receiving aspirin, 16 patients were receiving angiotensin-converting enzyme (ACE) in- critically ill patients with a mean age of 53 (27-82) and $47.1 \%$ were male. The mortality rate was $6.8 \%$. A total of $38.2 \%$ of the patients from Group 2 had pre-existing cardiovascular diseases (arterial hypertension: 21, arrhythmia: four, chronic heart failure: 10 , coronary artery disease: 14 ). All patients in Group 2 had pneumonia confirmed by chest computed tomography (CT), 41 with involvement of more than $50 \%$ of lung parenchyma. In 58 cases, this was complicated by ARDS. SpO2 fluctuated between 45 and $93 \%$.

Prior to hospitalization, 27 patients were receiving anticoagulants (Xarelto 10-30 mg: 14, enoxaparin $4000 \mathrm{U}$ : eight, aspirin $75-100 \mathrm{mg}$ : 34 ). All patients in Group 2 received enoxaparin $4000 \mathrm{U}$ od subcut. After laboratory tests and reevaluation of the risk of thrombosis, doses of anticoagulants were changed. D-dimer was $0.4-1.5 \mathrm{FEU} / \mathrm{ml}$ in 41 patients, $1.6-3 \mathrm{FEU} / \mathrm{ml}$ in $45,3.1-10$ in 11 , and $\geq 10$ in five. In all, 13 patients experienced adverse events (bleeding) from the anticoagulation; therefore, doses for these patients were adjusted or anticoagulation was ceased. A total of 96 patients received corticosteroids as part of their treatment during hospitalization. Mean hospitalization for this group was 14.1 days.

Study data revealed that Group 1 was managed with minimal infusion therapy and only $10.7 \%$ received anticoagulation. In contrast, Group 2 received preventive doses of anticoagulants and antiplatelets, and proper infusion therapy was administered. In Group 1, seven cases of MI were recorded on the 15-18th day of disease (three of these with a history of MI). In six cases, MI developed during hospitalization, and in one case, on the third day following hospital discharge (23rd day of disease). In Group 2, only three cases of MI were recorded (one of these with previous MI) (• Table 2).

Elevation of PLT count was recorded in the $3 \mathrm{rd}$ week of disease. The mean level of PLT in Group 1 was $813 \pm 473 \times 109 / \mu \mathrm{L}$ and $722 \pm 383 \times 109 / \mu \mathrm{L}$ in Group 2. There was also a drastic difference in other laboratory test results between the two groups (• Table 3).

Statistical revealed no significant difference in overall mortality (4.3\% vs $6.86 \%$, 
Table 7 Blood test results

\begin{tabular}{|l|l|l|}
\hline & Results & Normal range \\
\hline WBC & 11.06 & $4-10 \times 109 / \mu \mathrm{L}$ \\
\hline LYM & 1.03 & $1-3.0 \times 109 / \mu \mathrm{L}$ \\
\hline NEU & 8.84 & $1.6-7 \times 109 / \mu \mathrm{L}$ \\
\hline PLT & 1636 & $150-400 \times 109 / \mu \mathrm{L}$ \\
\hline RBC & 5.72 & $3.9-5.6 \times 1012 / \mu \mathrm{L}$ \\
\hline HGB & 165 & $110-160 \mathrm{~g} / \mathrm{l}$ \\
\hline CRP & 69 & $>5 \mathrm{mg} / \mathrm{l}$ \\
\hline D-dimer & 1.73 & $<0.55 \mathrm{FEU} / \mathrm{ml}$ \\
\hline PCT & 0.08 & $<0.05 \mathrm{ng} / \mathrm{ml}$ \\
\hline INR & 2.1 & $0.85-1.2$ \\
\hline APTT & 44.6 & $25-43 \mathrm{sec}$ \\
\hline Fibrinogen & 621 & $200-400 \mathrm{mg} / \mathrm{dl}$ \\
\hline $\begin{array}{l}\text { WBC white blood cell count, } \\
\text { RBC red blood cell count, } H G B \text { hempoglobin CRP C-reactive protein, } P C T \text { procalcitonin, INR interna- } \\
\text { tional normalized ratio, } A P P T\end{array}$ activated partial thromboplastin time, FEU fibrinogen-equivalent units \\
\hline
\end{tabular}

$p=0.441)$ and $\mathrm{MI}$ incidence (7.5\% vs $2.9 \%$, $p=0.149$ ) between the two groups. In contrast, there was a significant difference in incidence of severely and critically ill cases between the two groups ( $69.9 \%$ and $7.5 \%$ vs $75.5 \%$ and $20.6 \%, p<0.001$ ) (• Table 4).

Two cases of ST-segment elevation myocardial infarction (STEMI) in patients with COVID-19 in Group 2 are presented below. In both cases, patients were receiving lower doses of anticoagulants due to bleeding complications.

\section{Case presentations}

\section{Case 1}

A 51-year-old woman with a history of uncontrolled high blood pressure was admitted to hospital on the 8th day of COVID-19 disease with the following symptoms: fever, weakness, shortness of breath, cough, and bleeding from hemorrhoids. Chest CT was performed on admission, which revealed progressive bilateral nonspecific interstitial pneumonia with ground-glass opacity (GGO) covering $70 \%$ of lungs. Clinical findings for this patient on admission included: temperature: 37.2 C, SpO2: $86 \%$ in room air, $92 \%$ with oxygenation, heart rate (HR): $113 \mathrm{bpm}$, blood pressure (BP): 140/80 $\mathrm{mm} \mathrm{Hg}$, body mass index (BMI): 33 . Blood test results are presented in $\boldsymbol{0}$ Table 5.

The patient had previously taken hypotensive drugs once or twice a month only in critical situations. Before hospital- ization, the patient was taking only vitamins, aspirin, and azithromycin for 6 days.

A treatment regimen with a combination of steroid therapy (dexamethasone $12 \mathrm{mg} /$ day) and preventive anticoagulation (fraxiparine $4000 \mathrm{U} /$ day s.c.) was initiated. The patient received a low-dose anticoagulant due to bleeding hemorrhoids. Following hospitalization, the patient continued to have fever for 2 days, cough and dyspnea persisted, and on the third day ARDS developed and the patient was transferred to the intensive care unit (ICU).

Blood tests were repeated, the results of which are presented in $\mathbf{0}$ Table 6.

At $18 \mathrm{~h}$ following admission to the ICU, the patient experienced discomfort in the right shoulder. Electrocardiography (ECG) was performed, which revealed ST elevation in leads V1-V3. The troponin T level was also elevated (395 ng/L) and further increased to $948 \mathrm{ng} / \mathrm{L}$. Due to ARDS and low SpO2 (81\%) even with oxygenation, percutaneous coronary intervention ( $\mathrm{PCl}$ ) was not possible and the patient passed away soon after the diagnosis of STEMI.

\section{Case 2}

A 62-year-old man with cardiovascular risk factors, including coronary artery disease, hypertension, as well as previous $\mathrm{Ml}$ and $\mathrm{PCl}$, was admitted with COVID-19-induced pneumonia on the 8th day of disease. The patient had fever, weakness, and shortness of breath. COVID-19 was confirmed by real-time reverse transcription- polymerase chain reaction testing from a nasopharyngeal swab. Clinical findings after physical examination included: temperature: $38.1 \mathrm{C}, \mathrm{SpO2}$ : $83-84 \%$ in room air and $90 \%$ with oxygenation, HR: 92 bpm, BP: $140 / 80 \mathrm{~mm} \mathrm{Hg}$. ECG was without abnormalities. The patient had been treated with antibiotics and corticosteroids before hospitalization. ECG was performed on admission, revealing no significant abnormalities. Laboratory results are presented in $\mathbf{0}$ Table 7.

This patient also received a low-dose anticoagulant (nadroparine $4000 \mathrm{U} /$ day ubcut) due to severe nasal bleeding.

During day 1 of hospitalization, the patient had a drop in SpO2 to 78\% with oxygenation during minimal physical activity. There were signs of encephalopathy. On the 2nd day of hospitalization, the patient experienced severe chest pain and discomfort and had a drop in BP to $70 / 40 \mathrm{~mm} \mathrm{Hg}$. The 12-lead ECG before symptoms showed an extreme left axis deviation, $T$ wave inversion in lead III, and ascending (not significant) ST elevation in lead I and aVL (- Fig. 1). The 12-lead ECG performed immediately after symptoms showed ST elevation in leads II, III, and aVF, as well as reciprocal ST depression in leads V3-V6, extreme left axis (• Fig. 2).

The patient's troponin T levels came back elevated at $193.3 \mathrm{ng} / \mathrm{L}$ (normal: $20 \mathrm{ng} / \mathrm{L})$. The patient received heparin $10,000 \mathrm{U}$ i.v. and analgesics. After $1 \mathrm{~h}$, the troponin $\mathrm{T}$ level rose to $1807.2 \mathrm{ng} / \mathrm{L}$. Acute myocardial infarction with ST elevation was diagnosed and the patient was transferred to a hospital with a catheterization laboratory. Coronary angiography revealed a proximal lesion in the right coronary artery (RCA) with $85 \%$ stenosis, and another lesion in the distal RCA (with $90 \%$ stenosis) extending to the posterior descending artery, where thrombi were localized (- Fig. 3). Other coronary arteries were affected: $30 \%$ stenosis of the distal left anterior descending artery (LAD), 70\% stenosis of the proximal left circumflex artery (LCX), and $70 \%$ stenosis of the first diagonal artery. Immediate RCA stenting with a drug-eluting stent was performed (- Fig. 4). On the following day, selective $\mathrm{PCl}$ was performed with stenting of the LCX. Dual antiplatelet therapy consisting of oral clopidogrel (75 mg od) and aspirin 


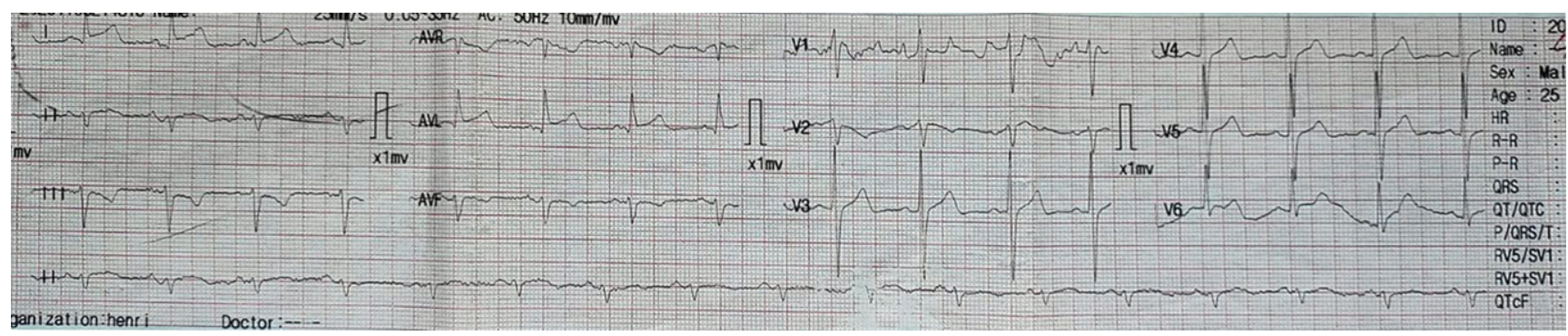

Fig. $1 \Delta$ Electrocardiogram on the 2nd day of hospitalization

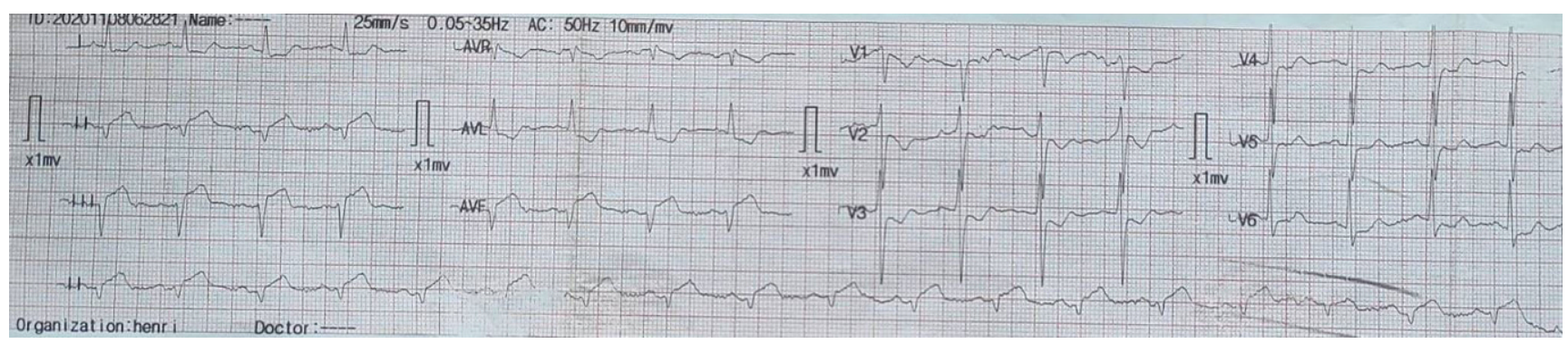

Fig. $2 \triangle$ A 12-lead electrocardiogram

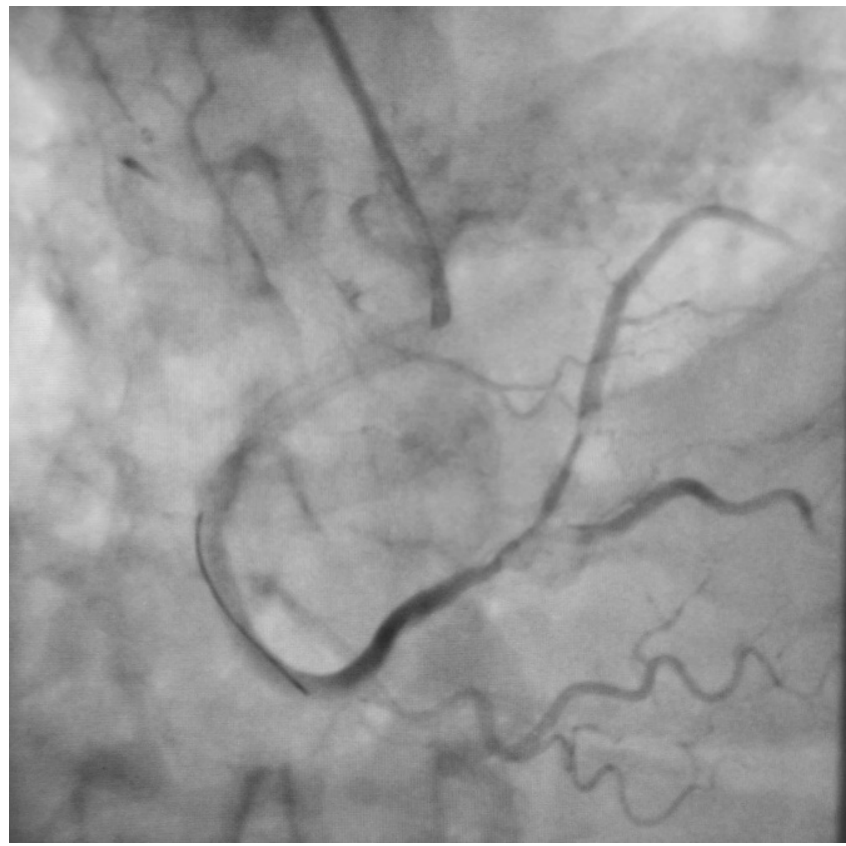

Fig. $3 \Delta$ Right coronary artery stenosis on coronary angiogram

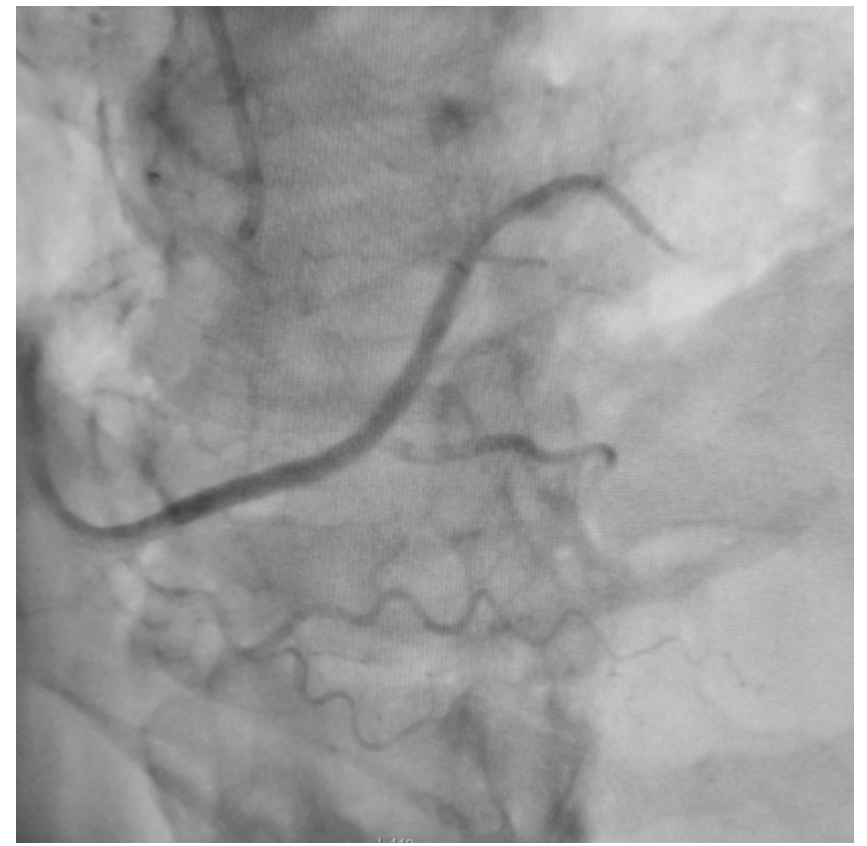

Fig. $4 \Delta$ Right coronary artery after percutaneous coronary intervention
(81 mg od) was initiated. After 32 days of prolonged hospitalization, the patient was discharged under long-term monitoring of a cardiologist and a hematologist. After 2 weeks, the patient was followed-up in an outpatient clinic. His physical strength and nutritional status had slightly improved, and there were no complications from the dual antiplatelet therapy.

\section{Conclusion}

A broad range of risk factors and potential cardiovascular complications were assessed and considered in the clinical management tactics.

The poorer outcomes in the early stages of the pandemic were associated with inadequate administration of anticoagulation treatment due to a lack of information about the novel virus and clinical management specificities.

Although Group 2 had significantly higher rates of severe cases, there was no significant difference in overall mortality and $\mathrm{Ml}$ incidence. The authors conclude that anticoagulants and antiplatelets were crucial for preventing cardiovascular complications especially in patients with comorbidities. Patients with high platelet 
levels were at higher risk of developing $\mathrm{MI}$, and subsequently of having a worse outcome.

\section{Corresponding address}

\section{Tigran Chilingaryan, MD}

2 Nairyan str., apt. 20, 2202 Abovyan, Armenia tigranchilingaryan7@gmail.com

\section{Declarations}

Conflict of interest. T. G. Chilingaryan, S. Tribunyan, H. V. Poghosyan, K. M. Sargsyan, H. B. Hovhannisyan, K. H. Karapetyan, L. G. Niazyan, and H. G. Hayrapetyan declare that they have no competing interests.

For this article no studies with human participants or animals were performed by any of the authors. All studies mentioned were performed in accordance with the ethical standards indicated in each case. Additional written informed consent was obtained from all individual participants or their legal representatives for whom identifying information is included in this article.

\section{References}

1. Guo $T$, Fan $Y$, Chen $M$, Wu $X$, Zhang $L$, He $T$, Wang H, Wan J, Wang X, Lu Z (2020) Cardiovascular implications of fatal outcomes of patients with Coronavirus disease 2019 (COVID-19). JAMA Cardiol 5(7):811-818. https://doi.org/10.1001/ jamacardio.2020.1017

2. Shi S, Qin M, Shen B et al (2020) Association of cardiac injury with mortality in hospitalized patients with COVID-19 in Wuhan, China. JAMA Cardiol 25:802-810

3. Zhou F, Yu T, Du R et al (2020) Clinical course and risk factors for mortality of adult inpatients with COVID-19 in Wuhan, China: a retrospective cohort study. Lancet 395:1054-1062

4. Chen T, Wu D, Chen H et al (2020) Clinical characteristics of 113 deceased patients with coronavirus disease 2019: retrospectivestudy. BMJ 368:m1091

5. Huang C, Wang Y, Li X et al (2020) Clinical features of patients infected with 2019 novel coronavirus in Wuhan, China. Lancet 395:497-506

6. Smeeth L, Thomas SL, Hall AJ, Hubbard R, Farrington P, Vallance P (2004) Risk of myocardial infarction and stroke after acute infection or vaccination. N Engl J Med 351:2611-2618

7. Prabhu SD (2004) Cytokine-induced modulation of cardiac function. Circ Res 95:1140-1153. https:// doi.org/10.1161/01.RES.0000150734.79804.92

8. Thygesen K, Alpert JS, Jaffe AS et al (2018) Fourth universal definition of myocardial infarction (2018). J Am Coll Cardiol 72:2231-2264

9. Tang N, Li D, Wang X, Sun Z (2020) Abnormal coagulation parameters are associated with poor prognosis in patients with novel coronavirus pneumonia. J Thromb Haemost 18:844-847. https://doi.org/10.1111/jth.14768

10. CDC (2021) People with certain medical conditions

11. Libby P, Loscalzo J, RidkerPMetal (2018) Inflammation, immunity, and infection in atherothrombosis: JACC review topic of the week. J Am Coll Cardiol 72:2071-2081

\section{Nutzen einer Antikoagulation bei der Prävention eines Myokardinfarkts und der Verbesserung der Prognose bei COVID-19-Patienten}

Hintergrund: „Coronavirus disease 2019“ (COVID-19) ist mit kardiovaskulären (KV) Komplikationen, einschließlich Myokardinfarkt (MI), Myokarditis, Arrhythmien und venösen Thrombembolien, assoziiert. Die Infektion verläuft bei Menschen mit vorbestehenden KV-Erkrankungen schwerer, bei denen systemische Inflammation aufgrund der Hyperzytokinämie, Hyperkoagulation sowie erhöhte Hämatokrit- und Thrombozytenwerte zu einem erhöhten KV-Risiko beitragen könnten. Die Autoren stellen die Hypothese auf, dass ein Herzinfarkt bei Menschen mit präexistenten KVErkrankungen durch Antikoagulanzien und Thrombozytenaggregationshemmer verhindert werden kann.

Methode: In die Kohortenstudie wurden Patienten mit bestätigter COVID-19-Diagnose aufgenommen. Deren klinische Parameter und Labordaten, Gesamtsterblichkeit und kardiovaskuläre Mortalität, MI-Inzidenz und die Behandlungsmodalitäten wurden, abhängig vom Zeitraum des Krankenhausaufenthalts (40-Tages-Zeitraum im April/Mai [Gruppe 1] bzw. Oktober/November [Gruppe 2]), verglichen.

Ergebnisse: Insgesamt wurden 195 Patienten in die Studie aufgenommen: 93 in Gruppe 1 und 102 in Gruppe 2, davon 36,5\% (Gruppe 1) bzw. 38,2\% (Gruppe 2) mit vorbestehender KV-Erkrankung. Die Patienten in Gruppe 1 erhielten eine Infusionstherapie, nur 10,7\% wurden mit Antikoagulanzien behandelt. Bei Gruppe 2 kamen präventiv Antikoagulanzien und Thrombozytenaggregationshemmer zusätzlich zur Infusionstherapie zum Einsatz. In Gruppe 1 erlitten 7 Patienten einen MI, in Gruppe 2 nur 3. Keine signifikanten Unterschiede zwischen beiden Gruppen wurden bezüglich der Gesamtsterblichkeit (4,3\% vs. $6,86 \%, p=0,441)$ und MI-Inzidenz $(7,5 \%$ vs. $2,9 \%, p=0,149)$ festgestellt, jedoch hinsichtlich der Inzidenz schwerer und kritisch kranker Fälle $(69,9 \%$ und $7,5 \%$ vs. $75,5 \%$ und $20,6 \%, p<0,001)$.

Schlussfolgerungen: Schlechtere Behandlungsresultate in der frühen COVID-19Phase waren mit inadäquater Antikoagulation aufgrund fehlender Kenntnisse über das neue Virus assoziiert. Trotz der signifikant schwereren Verläufe ergaben sich keine signifikanten Unterschiede bezüglich der Gesamtsterblichkeit und der Herzinfarktinzidenz bei Patienten unter Antikoagulation.

\section{Schlüsselwörter}

Lungenentzündung · Perkutane koronare Intervention · STEMI - Akute koronare Syndrome . Thrombose

12. Gennaro G, Sean P, Anuradha L, Vivek Y, Hillary A, Johnston-Cox Jl, Jonathan L, Valentin F (2020) Coronavirus and cardiovascular disease, myocardial injury, and arrhythmia. J Am Coll Cardiol 76(17):2011-2023. https://doi.org/10.1016/j.jacc. 2020.08.059

13. van de Veerdonk FL, Netea MG, Dinarello CA, Joosten LA (2011) Inflammasome activation and $\mathrm{IL}-1$ beta and IL-18 processing during infection. Trends Immunol 32:110-116

14. Vallance $P$, Collier J, Bhagat K (1997) Infection, inflammation, and infarction: does acute endothelial dysfunction provide a link? Lancet 349:1391-1392

15. Shi W, Lv J, Lin L (2020) Coagulopathy in COVID19: focus on vascular thrombotic events. J Mol Cell Cardiol 146:32-40. https://doi.org/10.1016/j. yjmcc.2020.07.003 